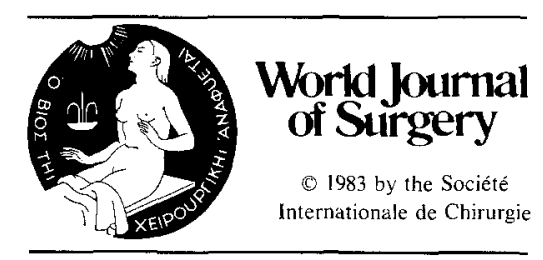

\title{
Combined Fluid and Corticosteroid Therapy in Septic Shock in Puppies
}

\author{
Robert H. Connors, M.D., Arnold G. Coran, M.D., Robert A. Drongowski, M.S., \\ and John R. Wesley, M.D. \\ Section of Pediatric Surgery, University of Michigan Medical School and Mott Children's Hospital, \\ and Pediatric Surgical Research Laboratories, Mott Children's Hospital, Ann Arbor, Michigan, U.S.A.
}

The optimal treatment of septic shock remains controversial. In order to evaluate the efficacy of fluid resuscitation and corticosteroid administration, the following experimental study was undertaken. Forty-five puppies (1.6-5.4 $\mathrm{kg}$ ) were randomly divided into 9 groups generated by combining 3 different fluid regimens and 3 different timings for steroid administration. Arterial, venous, and pulmonary artery catheterization allowed continuous hemodynamic and metabolic monitoring. Septic shock was achieved by a slow bolus infusion of $10^{9} / \mathrm{kg}$ Escherichia coli organisms. Methylprednisolone $(30 \mathrm{mg} / \mathrm{kg}$ ) was administered either $30 \mathrm{~min}$ before bacterial infusion, at the time of shock, or $30 \mathrm{~min}$ after shock. When cardiac output dropped to less than $50 \%$ of control values, 1 of the 3 following fluid resuscitation regimens was begun: $5 \%$ albumin in lactated Ringer's (LR) at $35 \%$ of the estimated blood volume (EBV), LR at $105 \% \mathrm{EBV}$, or $5 \%$ albumin in LR at $105 \%$ EBV.

When all the groups were combined, early steroid treatment was more effective than delayed therapy, yielding respective survival rates of $47 \%$ and $7 \%$ at $180 \mathrm{~min}$. Similarly, the large-volume resuscitation groups achieved a $43 \%$ survival rate compared to $13 \%$ for the smaller fluid protocols. Neither early steroid therapy nor large volume fluid therapy was shown by itself to increase survival, however. Despite steroid pretreatment, none of the puppies given the lower-volume infusion survived. Also, despite large-volume fluid resuscitation, there were no survivors when this was combined with steroid treatment that was delayed $30 \mathrm{~min}$. Only by combining early steroid administration with large-volume fluid therapy was a markedly

A portion of this study was supported by a grant from the Upjohn Company, Kalamazoo, Michigan.

Reprint requests: Arnold G. Coran, M.D., Section of Pediatric Surgery, Mott Children's Hospital, Room F7516, Box 66, Ann Arbor, Michigan 48109, U.S.A. increased survival rate achieved: $60 \%$ with simultaneous steroid treatment, and $70 \%$ with steroid pretreatment.

A definite increase in animal survival has, therefore, been shown in the acute period of severe septic shock using a combination of high-volume fluid resuscitation and the early administration of steroids.

Septic shock continues to be a clinical state that causes significant rates of mortality. The optimal treatment of this pathological condition remains a matter of controversy. Questions about the efficacy of corticosteroid therapy in treating shock states continue to be part of this controversy. The use of fluid resuscitation and antibiotics has generally gained wider acceptance, however.

Evaluation of the relative importance of each component of therapy has been difficult. Many studies have poorly quantitated the volume and kind of fluid resuscitation used. The timing and type of steroid administration has also varied. The use of shock models of different types and variable severity has further complicated the evaluation of previous studies.

Several experimental models have suggested beneficial results from corticosteroids alone [1-3], while others (including one from our laboratory) have shown no effect [4-6]. Other studies have suggested that steroid treatment must be combined with antibiotic therapy and fluid resuscitation to show a clear additional benefit $[7,8]$.

Through the use of a puppy model of live Escherichia coli shock, identical to that used in our previous studies [5,9], this experiment combines carefully quantitated fluid resuscitation with a steroid administration protocol in order to assess the efficacy of a variety of combinations of these 2 modalities. 
Table 1. Experimental group protocols.

\begin{tabular}{|c|c|}
\hline Group number & Regimen \\
\hline 1 & $\begin{array}{l}\text { MPSS } 30 \text { min before } E . \text { coli; LR } \\
105 \% \text { EBV }\end{array}$ \\
\hline 2 & $\begin{array}{l}\text { MPSS } 30 \text { min before } E \text {. coli; } 5 \% \text { albu- } \\
\text { min in LR } 35 \% \text { EBV }\end{array}$ \\
\hline 3 & $\begin{array}{l}\text { MPSS } 30 \text { min before } E \text {. coli; } 5 \% \text { albu- } \\
\text { min in LR } 105 \% \text { EBV }\end{array}$ \\
\hline 4 & MPSS at shock; LR $105 \%$ EBV \\
\hline 5 & $\begin{array}{l}\text { MPSS at shock; } 5 \% \text { albumin in LR } \\
35 \% \text { EBV }\end{array}$ \\
\hline 6 & $\begin{array}{l}\text { MPSS at shock; } 5 \% \text { albumin in LR } \\
105 \% \text { EBV }\end{array}$ \\
\hline 7 & $\begin{array}{l}\text { MPSS } 30 \text { min after shock; LR 105\% } \\
\text { EBV }\end{array}$ \\
\hline 8 & $\begin{array}{l}\text { MPSS } 30 \text { min after shock; } 5 \% \text { albu- } \\
\text { min in LR } 35 \% \text { EBV }\end{array}$ \\
\hline 9 & $\begin{array}{l}\text { MPSS } 30 \text { min after shock; } 5 \% \text { albu- } \\
\text { min in LR } 105 \% \text { EBV }\end{array}$ \\
\hline
\end{tabular}

\section{Materials and Methods}

Forty-five mongrel puppies $(1.6-5.4 \mathrm{~kg})$ were randomly divided into 9 groups. A subcutaneous injection of $50 \mathrm{ml} / \mathrm{kg}$ of normal saline ensured adequate hydration during a 12-hour fast before the experiment. Pentobarbital anesthesia $(25 \mathrm{mg} / \mathrm{kg})$ was given and femoral artery and vein catheterization was performed bilaterally. A pediatric thermal dilution cardiac output catheter was passed through the pulmonary artery, and each animal was heparinized with $400 \mathrm{IU} / \mathrm{kg}$ of beef lung heparin. Baseline hemodynamic and metabolic measurements were made and repeated at regular intervals during the experiment.

Treatment protocols for the 9 groups are shown in Table 1. Each puppy was subjected to a rapid infusion of $10^{9}$ live $E$. coli (Dunwald strain B15:0125) per kilogram of body weight. Optical density measurements were made to determine the number of organisms infused. A $50 \%$ reduction in cardiac output was defined as shock. At the time of shock, each animal received fluid resuscitation. One of the 3 following treatments was used: lactated Ringer's (LR) at $105 \%$ of the estimated blood volume (EBV); $5 \%$ albumin in LR at $35 \%$ of the $\mathrm{EBV}$; or $5 \%$ albumin in LR at $105 \%$ of the EBV. EBV was calculated as $7 \%$ of the puppy's weight. In addition, each puppy received $30 \mathrm{mg} / \mathrm{kg}$ of intravenous methylprednisolone sodium succinate (MPSS) either 30 min before bacterial infusion, at the time of shock, or $30 \mathrm{~min}$ after shock was documented. These combinations thus defined the 9 experimental groups seen in Table 1. At the end of the 3-hour experimental period, the probability of long-term survival was assessed for each of the surviving animals. If the cardiac output was stable
Table 2. Survival rates in experimental septic shock.

\begin{tabular}{lllll}
\hline & $\begin{array}{l}\text { Number } \\
\text { of } \\
\text { number }\end{array}$ & $\begin{array}{l}\text { Mean } \\
\text { weight } \\
\text { animals }\end{array}$ & $\begin{array}{l}\text { Survival } \\
\text { rate at 180 } \\
\min (\%)\end{array}$ & $\begin{array}{l}\text { Predicted } \\
\text { long-term } \\
\text { survival rate } \\
(\%)\end{array}$ \\
\hline 1 & 5 & 3.1 & 80 & 40 \\
2 & 5 & 3.1 & 0 & 0 \\
3 & 5 & 4.2 & 60 & 40 \\
4 & 5 & 4.1 & 60 & 0 \\
5 & 5 & 4.5 & 20 & 0 \\
6 & 5 & 3.3 & 60 & 0 \\
7 & 5 & 3.8 & 0 & 0 \\
8 & 5 & 3.7 & 20 & 0 \\
9 & 5 & 3.8 & 0 & 0 \\
\hline
\end{tabular}

and measured at least $60 \%$ of the baseline value, long-term survival was predicted. The animals were sacrificed and correct placement of the pulmonary artery catheter was confirmed.

Standard laboratory methods were used to measure plasma glucose, cholesterol, triglycerides, free fatty acids, lactate, acid phosphatase, and arterial blood gases. The Wilcoxon signed rank test and Student's $t$-test were used for analysis, with $p$ values of less than 0.05 considered significant.

\section{Results}

\section{Survival}

Table 2 summarizes the general information about each group and lists the actual and predicted longterm survival. The 2 variables involved can be looked at individually and in combination. The first of these is the fluid resuscitation, and the second is the timing of the MPSS administration.

The large-volume regimens, either with or without albumin, showed comparable survival results and each was statistically different from the smallervolume resuscitation groups. When groups were combined, puppies given $105 \%$ of their EBV (groups 1, 3, 4, 6, 7, and 9) showed a survival rate of $43 \%$ (Table 3 ). Only $13 \%$ of the animals receiving $35 \%$ EBV treatment survived (groups 2, 5, and 8) (Table 4).

The second variable, the timing of MPSS administration, also brought about significant differences in survival rate. Steroid treatment $30 \mathrm{~min}$ after shock achieved only a $7 \%$ survival rate regardless of the type of fluid resuscitation (Table 5). The survival rate for animals treated at the time of shock or pretreated with MPSS was 47\% (Table 6). Despite pretreatment with MPSS, none of the smallvolume resuscitation puppies survived. The com- 
Table 3. Collected groups' survival: Large-volume fluid resuscitation.

\begin{tabular}{lll}
\hline $\begin{array}{l}\text { Group } \\
\text { number }\end{array}$ & Regimen & $\begin{array}{l}\text { Survival } \\
\text { rate }(\%)^{a}\end{array}$ \\
\hline 1 & $\begin{array}{l}\text { MPSS before E. coli; 105\% EBV- } \\
\text { LR }\end{array}$ & 80 \\
3 & MPSS before E. coli; 105\% EBV- & 60 \\
& $5 \%$ albumin in LR & 60 \\
4 & MPSS at shock; 105\% EBV-LR & 60 \\
6 & MPSS at shock; 105\% EBV-5\% & 60 \\
7 & albumin in LR \\
9 & MPSS after shock; 105\% EBV-LR & 0 \\
& MPSS after shock; 105\% EBV-5\% & 0 \\
\hline
\end{tabular}

${ }^{a}$ Combined survival rate, $43 \%$.

Table 4. Collected groups' survival: Small-volume fluid resuscitation.

\begin{tabular}{lll}
\hline $\begin{array}{l}\text { Group } \\
\text { number }\end{array}$ & Regimen & $\begin{array}{l}\text { Survival } \\
\text { rate }(\%)^{a}\end{array}$ \\
\hline 2 & $\begin{array}{l}\text { MPSS before E. coli; 35\% EBV-5\% } \\
\text { albumin in LR } \\
\text { MPSS at shock, 35\% EBV-5\% albu- } \\
\text { min in LR }\end{array}$ & 0 \\
5 & $\begin{array}{l}\text { MPSS after shock; 35\% EBV-5\% } \\
\text { albumin in LR }\end{array}$ & 20 \\
8 &
\end{tabular}

aCombined survival rate, $13 \%$.

bined survival rate of puppies similarly treated with MPSS, but given large-volume resuscitation (groups 1 and 3) was $70 \%$ (Table 7). Similar analysis showed that despite large-volume resuscitation in groups 7 and 9, there were no survivors when this treatment was combined with a delay in MPSS until 30 min after shock.

The groups receiving the combination of either steroid pretreatment or treatment at the time of shock with large-volume fluid resuscitation showed a $65 \%$ survival rate compared to only $8 \%$ for all other animals (Table 7). Seventy percent of the steroid pretreated-high-volume fluid resuscitation group survived and $40 \%$ of these animals met criteria for predicted long-term survival at the completion of the experimental period (Table 8). No other group yielded predicted long-term survivors.

\section{Hemodynamic Studies}

Cardiac output (CO) (Fig. 1) decreased significantly to less than $50 \%$ of control values in each group. Following fluid resuscitation, cardiac output increased markedly in each group. The best recoveries were seen with the larger-volume regimens, but differences were not statistically significant among
Table 5. Collected groups' survival: Delayed-corticosteroid treatment.

\begin{tabular}{llc}
\hline $\begin{array}{l}\text { Group } \\
\text { number }\end{array}$ & Regimen & $\begin{array}{c}\text { Survival } \\
\text { rate }(\%)^{a}\end{array}$ \\
\hline 7 & $\begin{array}{l}\text { MPSS after shock; 105\% EBV-LR } \\
\text { MPSS after shock; 35\% EBV-5\% } \\
\text { albumin in LR }\end{array}$ & 0 \\
& $\begin{array}{l}\text { MPSS after shock; 105\% EBV-5\% } \\
\text { albumin in LR }\end{array}$ & 0 \\
9 & . & \\
\hline
\end{tabular}

${ }^{a}$ Combined survival rate, $7 \%$.

Table 6. Collected groups' survival: Early corticosteroid treatment.

\begin{tabular}{lll}
$\begin{array}{l}\text { Group } \\
\text { number }\end{array}$ & Regimen & $\begin{array}{l}\text { Survival } \\
\text { rate }(\%)^{a}\end{array}$ \\
\hline 1 & $\begin{array}{l}\text { MPSS before E. coli; 105\% EBV- } \\
\text { LR }\end{array}$ & 80 \\
2 & $\begin{array}{l}\text { MPSS before E. coli; 35\% EBV- } \\
5 \% \text { albumin in LR }\end{array}$ & 0 \\
3 & MPSS before E. coli; 105\% EBV- & 60 \\
& $5 \%$ albumin in LR & 60 \\
4 & MPSS at shock; 105\% EBV-LR \\
5 & $\begin{array}{l}\text { MPSS at shock; 35\% EBV-5\% } \\
\text { albumin in LR }\end{array}$ \\
6 & $\begin{array}{l}\text { MPSS at shock; 105\% EBV-5\% } \\
\text { albumin in LR }\end{array}$ \\
\hline
\end{tabular}

${ }^{a}$ Combined survival rate, $47 \%$.

groups. Following this initial improvement, outputs again deteriorated in each group of animals. Only in group 6 puppies, who were given high-volume $5 \%$ albumin in LR resuscitation and steroids at the time of shock, was the cardiac output (CO) clearly statistically still elevated above shock levels at 15 min after resuscitation. In the puppies pretreated with steroids and given large-volume fluid resuscitation, the rate of decline in $\mathrm{CO}$ was slowed. Each group given steroids after $30 \mathrm{~min}$ of shock showed statistically significant drops in CO 15-30 min following fluid administration. While all other groups showed some decline, these differences were not statistically significant. The group given LR resuscitation at $35 \% \mathrm{EBV}$ and steroids at the time of shock had a more rapid decline of $\mathrm{CO}$ than the large-volume resuscitation group.

Mean blood pressures paralleled cardiac output measurements. Each group showed a recovery with fluid resuscitation. Only groups 1 and 3 (largevolume-steroid pretreatment groups) showed significant improvement in blood pressure when compared to the other animals. The improvement was short-lived in group 3 and slightly more sustained in group 1.

Pulse pressure decreased with the bacteremia in all the animals. There was an initial recovery with 
Table 7. Collected groups' survival: Early corticosteroid treatment and large-volume fluid resuscitation.

\begin{tabular}{lll}
\hline $\begin{array}{l}\text { Group } \\
\text { number }\end{array}$ & Regimen & $\begin{array}{l}\text { Survival } \\
\text { rate }(\%)^{a}\end{array}$ \\
\hline 1 & MPSS before E. coli; 105\% EBV-LR & 80 \\
3 & MPSS before E. coll; 105\% EBV-5\% & 60 \\
& albumin in LR & \\
4 & MPSS at shock; 105\% EBV-LR & 60 \\
6 & MPSS at shock; 105\% EBV-5\% albu- 60 \\
& min in LR
\end{tabular}

${ }^{a}$ Groups $1,3,4,6: 65 \%$; groups $2,5,7,8,9: 8 \%$.

Table 8. Predicted long-term survival.

\begin{tabular}{lll}
$\begin{array}{l}\text { Group } \\
\text { number }\end{array}$ & Regimen & $\begin{array}{l}\text { Survival } \\
\text { rate (\%) }\end{array}$ \\
\hline 1 & MPSS before $E$. coli; 105\% EBV-LR & 40 \\
3 & $\begin{array}{c}\text { MPSS before } E . \text { coli; } 105 \% \text { EBV-5\% } \\
\text { albumin in LR }\end{array}$ & 40 \\
& All other groups & 0 \\
\hline
\end{tabular}

fluid resuscitation, followed by further decline in all the groups.

\section{Metabolic Studies}

In each group, there was a significant acidosis measured after bacterial infusion. Mean $\mathrm{pH}$ values decreased to 7.0 or less in each group. The highvolume-early steroid treatment groups 1 and 3 maintained blood $\mathrm{pH}$ better than the other groups, but this trend was statistically significant only at a few points during the experiment (Fig. 2). Lactic acidosis was documented in each animal. Mean values for each group rose to at least $60 \mathrm{mg} / 100 \mathrm{ml}$ by the time fluid resuscitation was given. There were few statistically significant differences among groups. Group 1 had significantly lower lactate levels than groups 5, 7, and 9 at $30 \mathrm{~min}$ after resuscitation (Fig. 3).

Acid phosphatase levels rose significantly in each group. Variable responses were seen among the animals. There was a trend toward higher elevations in the low-volume groups, which reached statistical significance when groups 2 and 5 were compared to group 1 at $60 \mathrm{~min}$ (Fig. 4).

Serum glucose levels were quite variable and showed consistent decreases only as animals entered profound shock (Fig. 5). Group 2 did show a significant drop in values at $60 \mathrm{~min}$. Cholesterol levels all decreased during the shock state. The magnitude of the change was not consistent, however, and no definite trends were identifiable. Free fatty acids showed little change, with only groups 2

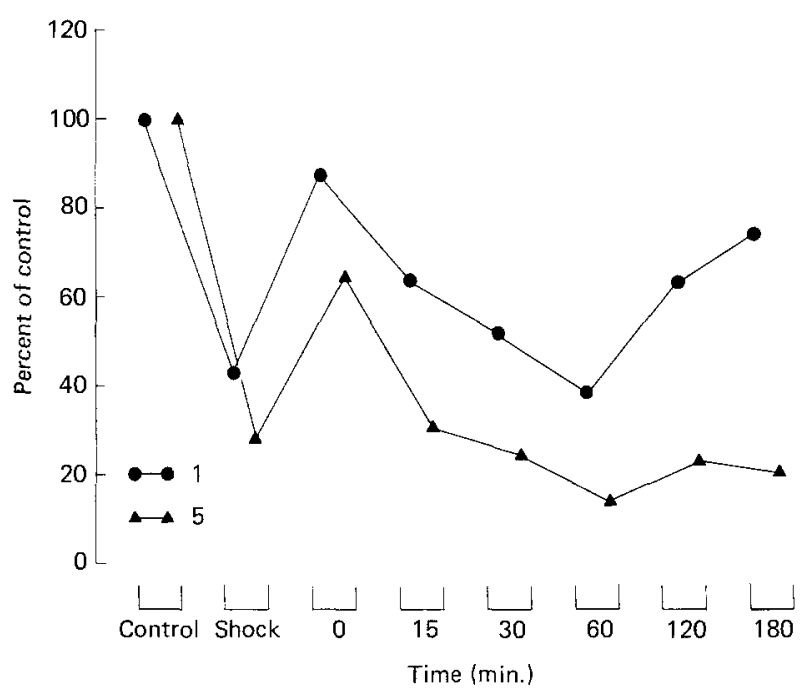

Fig. 1. Cardiac output changes in group 1 (MPSS $30 \mathrm{~min}$ before E. coli; LR $105 \% \mathrm{EBV}$ ) and group 5 (MPSS at shock; 5\% albumin in LR 35\% EBV). These 2 groups represent the 2 ends of the spectrum of fluid resuscitation.

and 3 showing early rises that were statistically significant. Serum triglycerides also showed no definite trends. Group 1 showed significant declines at 60 and $120 \mathrm{~min}$ and group 2 showed early significant elevations. Arterial $\mathrm{PO}_{2}$ and $\mathrm{PCO}_{2}$ were quite stable during the experimental period and showed no changes of statistical significance.

\section{Discussion}

The debate over the usefulness of corticosteroid therapy in shock has been active for many years and has remained largely unresolved. This study is directed at a specific area of that debate, namely, the usefulness of corticosteroids in the early phases of the treatment of severe $\left(\mathrm{LD}_{100}\right)$ bacteremic shock. Significant differences have been noted between true bacteremic and pure endotoxin shock [10]. We believe that a bacteremia model more closely approximates human septic shock than the shock state produced by endotoxin alone.

Previous studies have provided evidence both for and against the efficacy of steroids in this type of shock. Herman et al. [6] showed no protection against diffuse intravascular coagulation and kinin release in $E$. coli shock in the baboon with steroid pretreatment. Our laboratory [5] showed no significant increase in survival, cardiac output, carbohydrate metabolism preservation, or cellular membrane stabilization when MPSS was used without fluid resuscitation as the only treatment of septic shock in puppies. Coalson et al. [4] showed no protection against the microscopic damage to the 


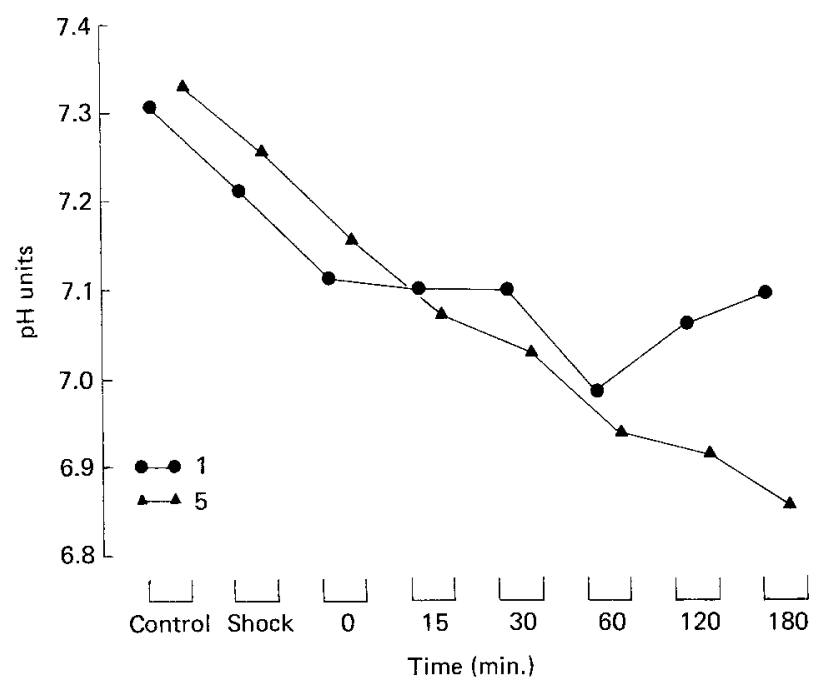

Fig. 2. Blood pH changes in groups 1 and 5 .

baboon liver, kidney, or adrenal glands with MPSS given $15 \mathrm{~min}$ after $E$. coli infusion.

Hinshaw et al. have reported increased survival using a combination of MPSS and antibiotic therapy (gentamicin at $9 \mathrm{mg} / \mathrm{kg}$ ) in both canine [8] and primate [7] $E$. coli shock. This difference in survival could not be shown for MPSS treatment alone, however. Sambhi and co-workers [11] have shown increased cardiac output and decreased peripheral resistance after dexamethasone treatment in controlled bacteremia in humans.

The experimental model used in this study has reliably produced lethal shock in untreated puppies in previous studies from our laboratory $[5,9]$. The use of immature animals may more closely approximate clinical shock in the pediatric age range. The magnitude of bacteremia is comparable to that used in other published studies [12]. Three of the theoretical advantages of corticosteroid therapy were evaluated: the positive inotropic effect on the heart, lysosomal membrane stabilization, and carbohydrate metabolism preservation. The efficacy of small- and large-volume fluid therapy was also evaluated.

The large-volume fluid regimens were clearly superior to the smaller-volume resuscitation protocols. Combined survival rate of animals given highvolume resuscitation ( $105 \%$ of the EBV) was $43 \%$. There were no statistically significant differences between the 5\% albumin group and those not given albumin. In contrast, only $13 \%$ of the puppies receiving $35 \%$ of their EBV as resucitation survived. Steroid pretreatment or treatment at the time of shock was more effective than treatment delayed until $30 \mathrm{~min}$ after shock. The survival rate with each of these 2 treatments was $47 \%$, compared to only $7 \%$ with delayed therapy.

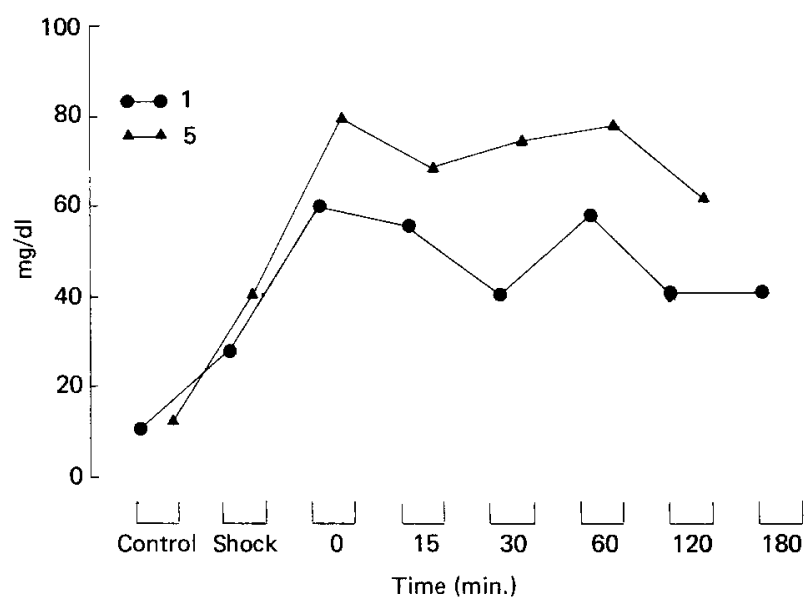

Fig. 3. Blood lactate changes in groups 1 and 5 .

Neither large-volume fluid resuscitation nor early steroid treatment, however, was effective alone in increasing survival. When the more favorable largevolume fluid resuscitation was combined with delayed steroid treatment in groups 7 and 9, there were no survivors. Similarly, when the more effective early steroid treatment was combined with lowvolume fluid resuscitation in groups 2 and 5, only a $10 \%$ survival was achieved. It was only by combining large-volume fluid resuscitation with early corticosteroid treatment that increased survival resulted. Groups 1, 3, 4, and 6, which combined these variables, yielded a $65 \%$ survival rate compared to only $8 \%$ for all other groups. Groups 1 and 3, which were pretreated with steroids, showed a combined $70 \%$ survival rate.

The importance of this trend toward better survival with earlier steroid treatment is substantiated by looking at cardiac output values. Forty percent of the puppies given steroid pretreatment and highvolume resuscitation maintained cardiac outputs of greater than $60 \%$ of control values at the end of the experiment and were, therefore, predicted longterm survivors. No other surviving animals met this criterion.

The exact mechanism for the increased survival documented in this experiment cannot be proven from our present data. Strong trends were noted in the early steroid treatment-large fluid volume groups toward higher cardiac outputs, lower acid phosphatase levels, and less acidosis. At various points during the experiment, these trends reached statistical significance. The survival figures show clear statistical significance.

In conclusion, in this model, a definite increase in animal survival has been shown in the acute phase of severe septic shock using a combination of highvolume fluid resuscitation and the early administration of corticosteroids. 


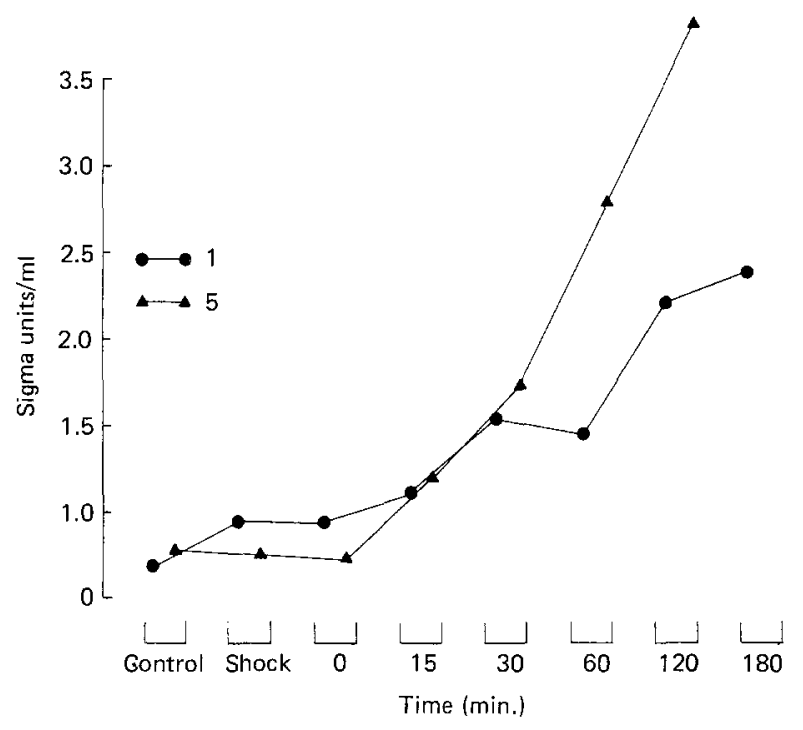

Fig. 4. Serum acid phosphatase changes in groups 1 and 5 .

\section{Résumé}

Le meilleur traitement du choc septique prête encore à controverse. Pour le déterminer, une étude expérimentale a été entreprise de manière à apprécier l'efficacité de la compensation liquidienne et celle des corticoïdes. Pour ce faire, 45 chiots $(1,6-$ $5,4 \mathrm{~kg}$ ) furent randomisés en 9 groupes en combinant l'administration de 3 types de liquide et celles des stéroïdes à 3 moments différents. Le cathétérisme artériel, veineux et celui de l'artère pulmonaire permirent l'étude continue de l'hémodynamique et des métabolismes. Le choc septique fut provoqué par l'injection lente d'un bolus constitué de $10^{9} / \mathrm{kg}$ d'E. Coli. Le méthylprednisolone (30 $\mathrm{mg} / \mathrm{kg}$ ) fut employé 30 minutes avant l'injection, au moment du choc ou encore après le choc.

Dès que le débit sanguin fut réduit de la moitié, la réanimation par apport liquidien fut assurée suivant 3 protocoles différents: injection de solution de Ringer enrichi de 5\% d'albumine (35\% du volume sanguin ou $105 \%$ du volume sanguin), solution de Ringer pur (105\% du volume sanguin).

Les résultats furent les suivants: l'administration précoce des stéroïdes fut plus efficace que l'administration tardive, se traduisant par un taux respectif de survie de $47 \%$ dans le premier cas et de $7 \%$ dans la seconde éventualité. De façon identique, l'injection importante de liquide se solda par un taux de survie de $43 \%$ alors que celui de l'injection limitée ne dépassa pas $7 \%$. Cependant, ni la corticothérapie précoce, ni la compensation liquidienne importante n'augmenta par elle-même la survie. Aucun des chiots qui furent soumis à la corticothérapie précoce mais ne reçurent que peu de liquide ne survécut. Il en fut de même lorsque le chiot reçut un

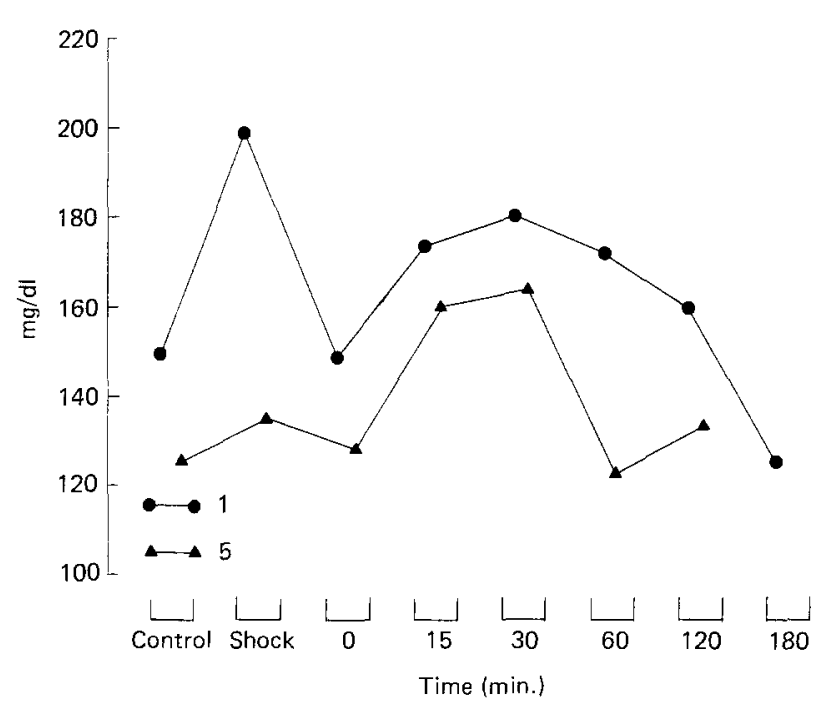

Fig. 5. Serum glucose changes in groups 1 and 5.

apport liquidien important et fut soumis à la corticothérapie tardive. C'est seulement en combinant la corticothérapie précoce et un apport liquidien important que le taux de survie fut amélioré: $70 \%$ quand la corticothérapie fut entreprise avant le choc, $60 \%$ lorsque les stéroïdes furent injectés au moment ou le choc fut provoqué.

Le choc est susceptible d'être jugulé seulement par l'administration précoce de corticoïdes et par un apport liquidien important; telle est la conclusion des auteurs.

\section{Resumen}

El tratamiento óptimo del shock séptico sigue siendo motivo de controversia. Con el objeto de evaluar la eficacia de la resucitación con líquido y la administración de corticoesteroides, se acometío el siguiente estudio experimental. Cuarenta y cinco cachorros $(1.6-5.4 \mathrm{~kg})$ fueron divididos al azar en 9 grupos generados por la combinación de 3 diferentes regímenes de líquidos y 3 diferentes programas para la administración de esteroides. El cateterismo arterial, venoso y de arteria pulmonar permitió la monitoría continua hemodinámica y metabólica. El shock séptico fue inducido mediante la infusión lenta de un bolo de $10^{9} / \mathrm{kg}$ de microorganismos $E$. coli. Se administró metilprednisolona $(30 \mathrm{mg} / \mathrm{kg}) 30$ minutos antes de la infusión bacteriana, o en el momento del shock, o 30 minutos después del shock. Una vez que el débito cardiaco hubo descendido a menos del $50 \%$ de los valores de control, uno de tres regímenes de resucitación fue iniciado: albúmina al 5\% en lactato de Ringer (LR) a razón de $35 \%$ del volumen sanguíneo estimado 
(VSE), LR a razón de $105 \%$ VSE, o albúmina al $5 \%$ en LR a razón de $105 \%$ VSE.

Al combinar los grupos, se vió que el tratamiento precoz con esteroide era más efectivo que el tratamiento tardío, con supervivencias respectivas de $47 \%$ y $7 \%$ a los 180 minutos. En forma similar, los grupos de resucitación con volumen alto lograron $43 \%$ de supervivencia, en comparación con $13 \%$ para los que fueron manejados con menor volumen de líquido. Sin embargo, ni la terapia con esteroide ni la terapia con alto volumen de liquido demostraron de por sí ser capaces de aumentar la supervivencia. A pesar del pretratamiento con esteroide, ninguno de los cachorros a los que se administró la infusión de menor volumen sobrevivió. Así mismi, a pesar de la resucitación con alto volumen de líquido, no hubo sobrevivientes cuando ésta fue combinada con tratamiento tardío con esteroide (demorado por 30 minutos). Sólo mediante la combinación de la administración precoz de esteroide con la terapia de alto volumen de liquido se logró una supervivencia notoriamente aumentada: $60 \%$ con el tratamiento simultáneo con esteroide, y $70 \%$ con el pretratamiento con esteroide.

En consecuencia, se demostró un aumento definido en la supervivencia de los animales en el período agudo de shock séptico utilizando una combinación de resucitación con alto volumen de líquido y la administración precoz de esteroides.

\section{References}

1. Clermont, H.G., Williams, J.S., Adams, J.T.: Steroid effect on the release of the lysosomal enzyme acid phosphatase in shock. Ann. Surg. 179:917, 1974

2. Pitcairn, M., Schuler, J., Erve, P.R., Holtzman, S., Schumer, W.: Glucocorticoid and antibiotic effect on

\section{Invited Commentary}

\author{
H. Harlan Stone, M.D. \\ University of Maryland, Baltimore, Maryland, U.S.A.
}

Reports on the usefulness of steroids in the treatment of septic shock continue to appear in print despite the fact that only 1 appropriately controlled, statistically valid clinical trial has shown true benefit in the final outcome once such shock has become established [1]. More than 50 similar investigations in humans alone have failed to reflect any long-term reduction in mortality rate. Although many impor- experimental gram-negative bacteremic shock. Arch. Surg. 110:1012, 1975

3. White, G.L., Archer, L.T., Beller-Todd, B.K., Hinshaw, L.B.: Increased survival with methylprednisolone in canine endotoxin shock. J. Surg. Res. 25:357, 1978

4. Coalson, J.J., Benjamin, B.A., Archer, L.T., BellerTodd, B.K., Spaet, R.H., Hinshaw, L.B.: A microscopic study of Escherichia coli shock in the baboon and the response to adrenocorticosteroid treatment. Surg. Gynecol. Obstet. 147:726, 1978

5. Connors, R.H., Coran, A.G., Wesley, J.R., Drongowski, R.A., Weintraub, W.H.: Corticosteroid therapy in hemorrhagic and septic shock in puppies. J. Ped. Surg. 15:790, 1980

6. Herman, C.M., Oshima, O., Erdos, E.G.: The effect of adrenocorticosteroid pretreatment on kinin system and coagulation response to septic shock in the baboon. J. Lab. Clin. Med. 84:731, 1974

7. Hinshaw, L.B., Archer, L.T., Beller-Todd, B.K., Coalson, J.J., Flournoy, D.J., Passey, R., Benjamin, B., White, G.L.: Survival of primates in $\mathrm{LD}_{100}$ septic shock following steroid/antibiotic therapy. J. Surg. Res. 28:151, 1980

8. Hinshaw, L.B., Beller-Todd, B.K., Archer, L.T., Flournoy, D.J., White, G.L., Phillips, R.W.: Recovery from lethal Escherichia coli shock in dogs. Surg. Gynecol. Obstet. 149:545, 1979

9. Benner, J.W., Polley, T.Z., Strodel, W.E., Drongowski, R.A., Weintraub, W.H., Wesley, J.R., Coran, A.G.: Fluid resuscitation in live E. coli shock in puppies. J. Ped. Surg. 15:527, 1980

10. Hinshaw, L.B., Soloman, L.A., Holmes, D.D., Greenfield, L.J.: Comparison of canine responses to Escherichia coli organisms and endotoxin. Surg. Gynecol. Obstet. 127:981, 1968

11. Sambhi, M.P., Weil, M.H., Udhoji, U.H.: Acute pharmacodynamic effects of glucocorticoids: Cardiac output and related hemodynamic changes in normal subjects and patients in shock. Circulation 31:523, 1965

12. Postel, J., Schloerb, P.R., Furtado, D.: Pathophysiologic alterations during bacterial infusions for the study of bacteremic shock. Surg. Gynecol. Obstet. $141: 683,1975$

tant parameters of critical organ function are improved by steroid administration to the patient or experimental animal in septic shock, eventual chances for survival remain about the same; only a prolongation of life to inevitable death has been the result. A complete bibliography of these studies carried out on experimental animals would comprise easily more than a thousand articles. Almost all of the reports have documented a significant protection by pretreatment and usually some reduction in mortality rate if the steroid is administered at the time of, or within a very few minutes of, the onset of the shock episode [2]. Any delay of more than $5 \mathrm{~min}$ or so has consistently eliminated any impact on survival by steroid therapy, that is, with 